\title{
Intrauterine foetal demise in pre-eclampsia - role of mifepristone: a case series
}

\author{
Kanika Chopra ${ }^{1}$, Suchitra $^{2 *}$, Prabha Lal ${ }^{1}$
}

\begin{abstract}
${ }^{1}$ Department of Obstetrics and Gynecology, Lady Hardinge Medical College, New Delhi, India
${ }^{2}$ Department of Obstetrics and Gynecology, J.L.N. Medical College, Ajmer, Rajasthan, India
\end{abstract}

Received: 12 April 2018

Accepted: 02 June 2018

\author{
*Correspondence: \\ Dr. Suchitra, \\ E-mail: narayan_jaiprakash@yahoo.co.in
}

Copyright: (C) the author(s), publisher and licensee Medip Academy. This is an open-access article distributed under the terms of the Creative Commons Attribution Non-Commercial License, which permits unrestricted non-commercial use, distribution, and reproduction in any medium, provided the original work is properly cited.

\begin{abstract}
Mifepristone is a steroid, which is a progesterone antagonist and is widely used for termination of pregnancies in all the trimester. It increases the sensitivity of the uterus to prostaglandins and ripens the cervix. Its role in inducing women with intra uterine demise is on the rise with varying dose regimen either alone or in combination with misoprostol. Among the various causes of intrauterine demise, one of the most important is hypertensive disorders of pregnancy complicating around $10 \%$ of pregnancies worldwide, Serum uric acid, a marker of oxidative stress is an important parameter in defining poor fetal outcome in women with pre-eclampsia. Induction of labour in women diagnosed with intrauterine demise is again a challenge in such women and mifepristone helps to a larger extent. In present case series, authors present six women presenting with pre-eclampsia with intrauterine demise, their clinical and biochemistry profile and responding to single dose of mifepristone of $200 \mathrm{mg}$ with mean induction to delivery interval being 40 hours. Henceforth, authors conclude that even single dose of mifepristone can work wonders taking into consideration the cost of the drug and thus can be definitely employed in daily clinical practice.
\end{abstract}

Keywords: Induction of labour, Intrauterine foetal demise, Mifepristone, Preeclampsia, Termination of pregnancy

\section{INTRODUCTION}

Fetal demise is defined as absence of cardiac activity of fetus after twenty weeks of gestation. Most common cause of fetal demise is unexplained. Fetal causes of death are congenital malformation, fetal infections; maternal causes are pre-eclampsia, diabetes mellitus, infection and placental causes are antepartum haemorrhage in the form of abruption or cord accidents. It is an unfortunate event in the life if the mother. Also, delay in the delivery of a dead fetus can be associated with intrauterine infections if the membranes are ruptured and a risk of consumptive coagulopathy. ${ }^{1}$ Thus, it is very important for the method of induction which is safe and effective as well. Mifepristone is a progesterone antagonist and can be used in women with intrauterine demise in all the trimester with high efficacy. Usually it is used along with misoprostol, a prostaglandin analogue, and helps in decreasing the dose of misoprostol and also its undesirable side effects. Present case series depicts one of the most important causes of intrauterine fetal death, pre-eclampsia. Hypertensive disorders of pregnancy are responsible for around 5\% of intrauterine demise. It has been seen that the risk of fetal death is more commonly seen in women diagnosed with preeclampsia in preterm period. ${ }^{2}$. Authors have used a single dose of mifepristone of $200 \mathrm{mg}$ and this dose has been shown to be really effective in induction in women with intra uterine fetal demise. A randomised clinical trial was undertaken on the use of mifepristone in the dose of 200 mg three times a day for two days as compared to placebo drugs and it was seen that labour occurred within 72 hours in significantly more women as compared to placebo. Mifepristone is usually used along with 
misoprostol in women with intrauterine demise and helps in decreasing induction to delivery interval considerably.

\section{CASE REPORT}

\section{Case 1}

A 30-year-old, G2P1L1, admitted at 24 weeks of gestation with high blood pressure and an ultrasound report suggestive of intra uterine demise of the fetus. Her previous baby was 6 years old, normal vaginal delivery and there was no history of high blood pressure during that pregnancy or in between the two pregnancies. Her blood pressure was $164 / 110 \mathrm{mmHg}$ and urine albumin with dipstick was $2+$. On per abdominal examination, it was a twenty-week uterus with normal tone. Her biochemistry profile was haemoglobin $13.8 \mathrm{gm} \%$, platelet count 1.92 lakh, serum uric acid was $6.4 \mathrm{mg} / \mathrm{dl}, 24$-hour urinary protein was $642 \mathrm{mg}$, fundus examination and ultrasound for kidneys was normal. Her prevaginal examination was done and a bishop scoring was 2. After stabilizing her blood pressure, decision for induction was taken and single dose of mifepristone of $200 \mathrm{mg}$ was given and she delivered within 52 hours.

\section{Case 2}

A, 24-year-old, primigravida at 30 weeks of gestation came with the complaint of inability to perceive fetal movements for one day. There was no history of headache, blurring of vision, epigastric pain, pain abdomen, bleeding or leaking per vaginum. On presentation her blood pressure was 150/110 $\mathrm{mmHg}$, urine albumin was $3+$. On per abdominal examination, uterus was 28 weeks, relaxed with normal tone cephalic presentation, liquor seems to be adequate in amount, and fetal heart sound was not localised by stethoscope. Ultrasound was done and suggestive of intrauterine demise. Her investigations were as follows haemoglobin $11.5 \mathrm{gm} \%$, platelet count 2.18 lakhs, serum uric acid $5.1 \mathrm{mg} / \mathrm{dl}, 24$-hour urinary protein was $1.27 \mathrm{gm}$, fundus examination and ultrasound for kidneys was normal. After starting her on antihypertensive and controlling her blood pressure, she was induced with single dose of mifepristone $200 \mathrm{mg}$, in view of poor bishops of 3 , and woman delivered within 33 hours of the dose.

\section{Case 3}

A primigravida, 28 years of age, referred from private hospital in view of high blood pressure and an ultrasound report suggestive of an intrauterine demise at the gestation of 38 weeks. She was asymptomatic with no history of high blood pressure in the past or feature of impending eclampsia. She didn't have history of decreased fetal movements as well. On admission her blood pressure was $160 / 102 \mathrm{mmHg}$ and urine albumin was nil. On per abdominal examination, uterus was 32 weeks, relaxed with normal tone, cephalic presentation with less liquor clinically. Her investigations were as follows haemoglobin $13.5 \mathrm{gm} \%$, platelet count 2.4 lakhs, serum uric acid $5.4 \mathrm{mg} / \mathrm{dl}$, 24-hour urinary protein was $1.5 \mathrm{gm}$, fundus examination and ultrasound kidneys were normal. Antihypertensive were started and in view of poor bishops of 4 , the decision of induction with mifepristone was taken, and she delivered after 35 hours uneventfully.

\section{Case 4}

A gravida 5, para 2, abortion 2, live 0, 26-year-old woman admitted with history of previous two preterm lower segment caesarean sections in view of antepartum eclampsia in the first pregnancy and anhydramnios with severe pre-eclampsia in the second pregnancy and intrauterine demise at 30 weeks of gestation in present pregnancy. There was no history of high blood pressure in between the interconceptional period. On admission her blood pressure was $146 / 100 \mathrm{mmHg}$, urine albumin was $3+$. On per abdominal examination, she was 28 weeks of gestation, it was breech presentation with clinically less liquor, and fetal heart rate was not localised by stethoscope. She had a bishop's score of 2 . Her investigations were as follows- haemoglobin $12.3 \mathrm{gm} \%$, platelet count 2.2lakhs, serum uric acid $2.3 \mathrm{mg} / \mathrm{dl}, 24$-hour urinary protein was $120 \mathrm{mg}$, fundus examination and ultrasound kidneys were normal. After stabilizing her blood pressure, she was induced with single dose of mifepristone and delivered after 22 hours.

\section{Case 5}

A 34-year-old, gravida 3, para 2, live 2 with previous two normal vaginal deliveries at home with no history of high blood pressure during the pregnancies or thereafter, presented with the complaint of headache and inability to perceive the fetal movements for one day at the gestation of 36 weeks. Woman was showing in some dispensary till then and had normal blood pressure. On admission, her blood pressure was $160 / 106 \mathrm{mmHg}$, urine albumin was $3+$. On per abdominal examination, it was a 32-week uterus, cephalic presentation, liquor clinically less in amount and fetal heart was not audible. Ultrasound was done and was suggestive of intra uterine demise. She had a bishop's score of 4 . Her investigations were as followshaemoglobin $11.5 \mathrm{gm} \%$, platelet count 2.1 lakh, serum uric acid $5.4 \mathrm{mg} / \mathrm{dl}$, 24-hour urinary protein $365 \mathrm{mg}$, fundus and ultrasound of kidneys were normal. She was induced with single dose of $200 \mathrm{mg}$ of mifepristone and delivered after 14 hours of the dose.

\section{Case 6}

A 20-year-old woman, gravida 3, abortion 2, at 36 weeks of gestation, came with complaint of decreased fetal movements for last two days and headache. She was referred from primary health centre in view of high blood pressure of $170 / 110 \mathrm{mmHg}$. On admission her blood pressure was $180 / 110 \mathrm{mmHg}$, urine albumin $4+$. On per abdominal examination, her uterus was 28 weeks, with 
fetus in cephalic presentation, liquor clinically less and fetal heart sound absent. After stabilising her blood pressure, ultrasound was done, and it confirmed the diagnosis of intrauterine demise. Her haemoglobin was $13.6 \mathrm{gm} \%$, platelet count 2.61lakhs, serum uric acid $6.5 \mathrm{mg} / \mathrm{dl}$, 24-hour urinary protein $2.2 \mathrm{gm}$, fundus examination was suggestive of grade 1 hypertensive retinopathy, and ultrasound kidneys was normal. In view of poor bishops of 3, decision to induce with mifepristone was taken, and woman delivered after 18 hours of 200 mg of mifepristone.

Out of the six women studied in present case series, all women were in the gestational age of 24 weeks to 38 weeks with mean gestational age of 32.33 weeks. These women parity ranged from primigravida to gravid 5. They were hypertensive with systolic blood pressure more than $140 \mathrm{mmHg}$ and diastolic blood pressure more than $100 \mathrm{mmHg}$. Investigation profiles of women were as shown in table I. Urine albumin by dip stick method was positive in all the women except one. The 24-hour urinary protein was more than $300 \mathrm{mg}$ in 5 women out of six. Fundus examination was suggestive of grade I hypertensive retinopathy in one women only and normal in all others. Now considering the value of serum uric acid, which is defined as a significant biochemical variable in determining perinatal outcome authors found that, the mean serum uric acid level was $5.1 \mathrm{mg} / \mathrm{dl}$. All these women had poor bishops on presentation and single dose of mifepristone was the mode of induction decided for them. It was seen that all the women responded very well to the drug, with average induction to delivery interval being 40 hours without any complications reported and without the need for any further intervention as-well.

Table 1: Relative risk of abnormal Doppler indices with adverse perinatal outcome.

\begin{tabular}{|c|c|c|c|c|c|c|c|c|}
\hline Case & $\begin{array}{l}\text { Blood } \\
\text { pressure }\end{array}$ & $\begin{array}{l}\text { Urine } \\
\text { albumin }\end{array}$ & $\begin{array}{l}\text { Uric } \\
\text { acid }\end{array}$ & $\begin{array}{l}24 \text { hrs } \\
\text { urine } \\
\text { protein } \\
\text { (gm) }\end{array}$ & Fundus & $\begin{array}{l}\text { Mifepristone } \\
\text { dose }\end{array}$ & $\begin{array}{l}\text { Induction to } \\
\text { delivery } \\
\text { interval (hrs) }\end{array}$ & $\begin{array}{l}\text { Placental } \\
\text { Histopathology }\end{array}$ \\
\hline 1 & $164 / 110$ & $2+$ & 6.4 & 0.642 & Normal & $200 \mathrm{mg}$ & 52 & $\begin{array}{l}\text { Placental infarction, } \\
\text { microcalcification, } \\
\text { fibrinoid changes }\end{array}$ \\
\hline 2 & $150 / 110$ & $3+$ & 5.1 & 1.27 & Normal & $200 \mathrm{mg}$ & 33 & $\begin{array}{l}\text { Placental infarction, } \\
\text { microcalcification, } \\
\text { fibrinoid changes }\end{array}$ \\
\hline 3 & $160 / 102$ & Nil & 5.4 & 1.5 & Normal & $200 \mathrm{mg}$ & 35 & $\begin{array}{l}\text { Placental infarction, } \\
\text { microcalcification, } \\
\text { fibrinoid changes, } \\
\text { syncytial knot }\end{array}$ \\
\hline 4 & $146 / 100$ & $3+$ & 2.3 & 0.12 & Normal & $200 \mathrm{mg}$ & 22 & $\begin{array}{l}\text { Placental infarction, } \\
\text { microcalcification, } \\
\text { fibrinoid changes }\end{array}$ \\
\hline 5 & $160 / 106$ & $3+$ & 5.4 & 0.365 & Normal & $200 \mathrm{mg}$ & 14 & $\begin{array}{l}\text { Meconium staining, } \\
\text { microcalcification }\end{array}$ \\
\hline 6 & $180 / 110$ & $4+$ & 6.5 & 2.2 & $\begin{array}{l}\text { Grade } 1 \\
\text { hypertensive } \\
\text { retinopathy }\end{array}$ & $200 \mathrm{mg}$ & 18 & Placental hemorrhage \\
\hline
\end{tabular}

\section{DISCUSSION}

Intrauterine demise is a dreadful event in the life of the mother and the entire family and thus the importance of a method that can reduce induction to delivery interval and also is free from any adverse side effects.

Among the various causes of intrauterine demise, hypertensive disorder of pregnancies is one of the most predominate cause as discussed in present case series. Mifepristone, a progesterone antagonist is one such agent. The pharmacokinetics of oral administration are characterised by rapid absorption with a long half-life of 25-30 hours. $^{3}$
It is usually used along with misoprostol, a prostaglandin E1 analogue, in all the trimester and has been widely studied in women with intrauterine demise. It has been seen to be highly effective in reducing induction to delivery interval. Present aim was to assess the usefulness of a single dose of mifepristone in induction of women with intrauterine demise, taking into consideration the high cost of this drug and also the side effects of the drug used along with it and to study the induction delivery interval. Initially, misoprostol was the only drug used as the mode of induction in women with intrauterine demise. Leon $P$ reviewed 14 randomised controlled trial. ${ }^{4}$ It was studied that induction to delivery interval was found to be shorter with the administration of 600 
micrograms of misoprostol vaginally as compared to 400 micrograms.

Vaginal administration of misoprostol was associated with increased induction to delivery interval but lesser gastrointestinal side effects as compared to oral or sublingual route. But, none of the studies were performed formulating the dose of misoprostol in women with second and third trimester intrauterine demise. Also, the majority of published guidelines contraindicate the use of misoprostol in women with uterine scars due to its high propensity for ruptures. ${ }^{5}$

Taking into consideration the use of mifepristone along with misoprostol, among various published studies it was seen that use of misoprostol alone regimen has an induction to delivery interval of 10-19 hours as compared to mifepristone- misoprostol combination regimen where it was just 7-10 hours. ${ }^{6-11}$

Wagaarachi et al did the largest case series using a combination regimen for the management of late intrauterine fetal death and reported a mean induction to delivery interval of 8.5 hours. ${ }^{12}$ The optimum mifepristone - misoprostol interval of 36 to 48 hours should be observed to reduce the dose of misoprostol required and thus its side effects. In another study done by Gupta $\mathrm{S}$ et al, data from 72 women with intrauterine fetal death between the gestational age of $24-42$ weeks were analysed. ${ }^{13}$ Mifepristone $200 \mathrm{mg}$ was followed by misoprostol (200- 50 micrograms) depending on the gestation after $36-48$ hours in group A as compared to only misoprostol in group B. In group A, 93.3\% women delivered within 24 hours of first dose of misoprostol while in group B in was $80.5 \%$. Cabrol D et al did a double blinded control study in women with intra uterine demise. ${ }^{14}$ Mifepristone was given in the dose of $600 \mathrm{mg}$ per day for two days and was considered effective in $63 \%$ cases. Tolerance to the drug was found to be good and was suggestive to be an alternative to prostaglandins in this indication. As per the knowledge none of the case series has studied the response of single dose of mifepristone alone of $200 \mathrm{mg}$. In comparison with the study by Cabrol D et al, present case series had an induction to delivery interval of 40 hours as compared to 39 hours in their study.

\section{CONCLUSION}

Mifepristone is an effective agent even in a single dose of $200 \mathrm{mg}$ for induction in women with intrauterine demise. Although a study at much larger scale is required to implement its use at a larger scale for the benefit of the woman as well as the obstetrician.

Funding: No funding sources

Conflict of interest: None declared
Ethical approval: The study was approved by the Institutional Ethics Committee

\section{REFERENCES}

1. Pritchard JA. Fetal death in utero. Obstet Gynecol. 1959;14:573-80.

2. Ahmad AS, Samuelsen SO. Hypertensive disorders in pregnancy and fetal death at different gestational lengths: a population study of 2121371 pregnancies. BJOG. 2012;119:1521-8.

3. Heikinheimo O. Clinical phatmacokinetics of mifepristone. Clin Pharmacokinet. 1997;33:7-17.

4. Ponce de Leon RG. Wing DA. Misoprostol for termination of pregnancy with intrauterine featl demise in the second and third trimester of pregnancy: a systematic review. Contraception. 2009;79:259-71.

5. Royal College of Obsterician and Gynaecologists. Green top guidelines No.55: Late Intrauterine Fetal Death and Stillbirth. London: RCOG; 2011.

6. Bugalho A, Bique $\mathrm{C}$, Machungo $\mathrm{F}$, Faaundes A. Induction of labour with intravaginal misoprostol in intrauterine fetal death. Am J Obstet Gynecol. 1994;171:538-41.

7. Chittacharoen A, Herabutaya Y, Punyavachira P. A randomized trial of oral and vaginal misoprostol to manage delivery in cases of fetal death. Obstet Gynecol. 2003;101:70-3.

8. Draycott T, Hawkes N, Read MD. Induction of labour with vaginal misoprostol after intrauterine deaath from 24 weeks gestation. J Obstet Gynecol. 1996;16:517-8.

9. Srisomboon J, Singchai S. A comparison between $25 \mathrm{Ig}$ and $50 \mathrm{Ig}$ of intravaginal misoprostol for labour induction. J Med Assoc Thai. 1998;81:779-83.

10. Dodd JM. Misoprostol for the induction of labour at term. PhD thesis. Department of Obstetrics and Gynaecology, Faculty of Health Sciences, University of Adelaide, 2005.

11. Fletcher HM, Wharfe G, Simeon D, Mitchell S, Brown D. Induction of labour with intravaginal misoprostol versus dinoprostone in intrauterine death: a retrospective study. J Obstet Gynaecol. 1996;16:155-8.

12. Wagaarachchi PT, Ashok PW, Narvekar NN, Smith NC, Templeton A. Medical management of late intrauterine death using a combination of mifepristone and misoprostol. BJOG. 2002;109:443-7.

13. Shilpa G, Bhumika K, Ajesh D. Mifepristone and misoprostol versus misoprostol alone in management of late intrauterine fetal death. Int $\mathbf{J}$ Reprod Contracept Obstet Gynecol. 2016 sep;5(9):2935-38

14. Cabrol D, Dubois C, Cronje H, Gonnet JM et al. Induction of labour with mifepristone in intrauterine fetal death. Am J Obstet Gynecol. 1990 Aug;163(2): 540-2.

Cite this article as: Chopra $\mathrm{K}$, Suchitra, Lal $\mathrm{P}$, Intrauterine foetal demise in pre-eclampsia: role of Mifepristone- A case series. Int J Reprod Contracept Obstet Gynecol 2018;7:2952-5. 